Journal of Technology and Social for Community Service (JTSCS)

Vol. 2, No. 2, September 2021, page-page. 102 107

P-ISSN: 2723-455X

E-ISSN: 2723-2026

available online at: https://ejurnal.teknokrat.ac.id/index.php/teknoabdimas

\title{
PROGRAM LATIHAN KEBUGARAN JASMANI DALAM MENJAGA KESEHATAN DIMASA PANDEMI SMK KRIDAWISATA BANDAR LAMPUNG
}

\author{
Syaiful Ahdan ${ }^{1}$, Aditya Gumantan ${ }^{2}$, Adi Sucipto ${ }^{3}$ \\ ${ }^{1,2,3)}$ Universitas Teknokrat Indonesia
}

Email : $\underline{\text { Syaifulahdan@ @teknokrat.ac.id }}{ }^{1}$, Aditya.gumantan@teknokrat.ac.id ${ }^{2}, \underline{\text { Adi.sucipto@ teknokrat.ac.id }}$,

\begin{tabular}{lll}
\hline Received: (2 September 2021) & Accepted: (8 September 2021) & Published : (15 September 2021) \\
\hline
\end{tabular}

\begin{abstract}
This service activity is carried out with the aim of providing training programs and carrying out a healthy living culture for students of SMK Kridawisatsa Bandar Lampung. This activity is carried out by conducting training for active students in extracurricular sports consisting of 30 active students. To see the level of fitness in each student, an initial test was carried out which involved all active students in extracurricular sports. After doing the initial test, each student is given a schedule and training program for each child so that the child carries out the training program that has been made for the next three months with control by mentors and coaches prepared by the sports service team. Based on the results of the initial test, it has a fitness classification with an average of 65 and in the final test with an average of 85, thus getting an increase in students' fitness and knowledge of physical fitness so that this service is categorized as a program that runs well and effectively.
\end{abstract}

Keywords: Exercise program, physical fitness, healthy living culture

\begin{abstract}
Abstrak
Kegiatan pengabdian ini dilaksanakan dengan tujuan untuk memberikan program latihan dan melakukan budaya hidup sehat pada siswa SMK Kridawisatsa Bandar Lampung.Kegiatan ini dilakukan dengan melakukan pelatihan bagi siswa-siswa aktif dalam extrakulikuler olahraga yang terdiri dari siswa aktif berjumlah 30 orang siswa. Untuk melihat tingkat kebugaran dalam setiap siswa dilakukan sebuh tes awal yang melibatkan keseluruhan siswa aktif pada ektrakulikuler olahraga. Setelah melakukan tes awal setiap siswa diberikan jadwal dan program latihan permasing-masing anak sehingga anak melakukan program latihan yang telh dibuat selama tiga bulan berikutkanya dengan kontrol oleh mentor dan pelatih yang disiapkan oleh tim pengabdian olahraga. Berdasarkan hasil tes awal memilki klasifikasi kebugaran dengan rata-rata sebesar 65 dan pada tes akhir dengan rata-rata sebesar 85 dengan begitu mendapatkan peningkatan kebugaran dan pengetahuan siswa terdadap kebugaran jasamni sehingga pengabdian ini dikategorikan program yang berjalan dengan baik dan efektif
\end{abstract}

Kata Kunci: Program latihan, kebugaran jasmani, budaya hidup sehat

To cite this article:

Syaiful Ahdan, Aditya Gumantan, Adi Sucipto. (2021). PROGRAM LATIHAN KEBUGARAN JASMANI DALAM MENJAGA

KESEHATAN DIMASA PANDEMI SMK KRIDAWISATA BANDAR LAMPUNG. Journal of Technology and Social for Community Service (JTSCS), Vol(2), 102-107. 


\section{PENDAHULUAN}

Kebugaran jasamni merupakan aspek yang paling penting dalam mengisis aktifitas kesehari-harian setiap siswa. Aplikasi kebugaran jasmani didapatkan dalam pelajaran pendidikan jasmani yang dilakukan dalam kurikukul sekolah, aplikasi proses pembelajaran mengedepatkan dalam aspek kebugaran dan penegtahuan olahraga secara umum. Kebugaran jasmani dan kesehatan dua hal yang berbeda, dimana sehat adalah dimana kondisi tubuh dan organ berfungsi sebagaimana mestinya, dan bugar adalah dimana kondisi tubuh memilki fungsi oragn yang baik serta dalam melakukan aktivitas tidak mengalami kelelahan yang sangat berarti (Alamsyah, Hestiningsih and Saraswati, 2017). Artinya dalam hal ini kebugaran jasmani merupakan bagian dari kesehatan dimana orang yang bugar sudah pasti sehat dan orang yang bugar belum tentu bugar. Bugar itu sendiri merupakan aplikasi tubuh dalam meragamkan gerak secara baik tanpa mengalami kelelehan yang berarti (Gumantan and Mahfud, 2020)

Pendidikan jasmani dalam proses belajar mengatur pernecanaan program pemebelajaran yang berkaitan dengan tingkat kebugaran jasmani dan kesehatan setiap siswa disekolah. Perencanaan program latihan yang nantinya dilakukan dalam penerapan hidup siswa menjadi dasar pembentukan kebugaran dan kesehatan siswa diluar jam sekolah. Program latihan adalah sebuah program aplikasi penerapan yang terukur dan terncana yang menjadikan aspek-aspek kebugaran sebagai pramater tes (Mahfud and Gumantan, 2020). Aplikasi program latihan yang dilakukan secara keberlanjutan dan terus menerus menjadikan program latihan ini menjadi baik. Aplikasi program latihan bisa dilkukan dengan lebih terukur dan sistematis. Program latihan sendiri menjadi sebuah dasar keberhasilan dan ketercapain seseorang dalam melakukan aktivitas olahraga (Prasetio et al., 2018).

Kebugaran jasmani dan kesehatan berhubungan dengan rangkainan struktur tubuh dan jaringan otot yang ada dalam tubuh manusia. Terdiri dari penguatan kapasistas jantung, paru-paru, kekuatan otot tungkai, kekuatan otot lengan dan komponen kebugaran jasmani lainnya. Kekuatam otot tungkai selau behubungan dengan korelasi tingkat kebugaran jasmani seseroang sehingga pengutan otot tungkai menjadi sebuah dasar dalam pembeutkan dalam program latihan (Adhi and Gumantan, 2020). Selain itu indeks masa tubuh sesorang akan mempengaruhi kondisi tubuh dalam melakukan aktivitas gerak. Indeks masa tubuh merupakan pengukuran tingkat bodi masa index sesorang yang berkaitan dengan tingkat obesitas ataupun kekurusan seseorang (Mahfud, Gumantan and Nugroho, 2020).

Dimasa pandemi saat ini menjadi kehawatiran seseroang dalam melakukan aktivitas fisik seseroang menjadi kehawatiran yang sangat berlebihan. Tingakt kecemasan seseroang akan beperngaruh dalam peningktan hormon endofrin tubuh manusia, dimana hormon ini mempengaruhi metabolisme tubuh seseorang dalam mekakuktan aktivitas fisik (Annisa and Ifdil, 2016). Kecemasan akan berpengaruh dalam aktivitas belajar sesorang sehingga siswa dapat melakukannya dengan serius dalam menerima pelajaran oleh gurunya (Setiyani, 2018). Mengontrol tingkat kecemasan dengan melakukan aktivitas diluar rumah yang membuat tingkat kebahagian yang besar akan memunculkan peningkatan hormon endufrin sehingga metoblisme berjalan dengan baik.

Corona virus yang disebut dengan covid 19 terjadi enyebaran selama lebih dari satu tahun ini menyebabkan seseorang malas untuk bergerak keluar rumah dengan pembatasan yang diperketat oleh pemerintah menjadikan siswa malas untuk melakukan aktivitas fisik dan olahraga . Corona virus adalah virus yang proses penyebarannya berjalan dengan cepat sehingga masyarakat dilarang untuk melakukan aktivitas diluar rumah (Gumantan et al., 2020). Untuk itu pembutan porgam latihan yang dilakukan secara terukur dan sistematis dengan pengawasa yang baik oleh tim pengabdian akan menjadikan program ini yang mampu membantu siswa dalam melakukan aktivitas fisik secara baik.

Pengukuran kebugaran jasmani ini sendiri akan dilakukan dengan dua kali dimana akan meilihat tes awal dan tes akhir siswa. Pengkuran berupa tes kpasistas paru dan jantung sperti bleep test, pengkuran denyut nadi istrihar sperti Harvd stetp test, pengkuran kekuatan tungkai standing broad jumpt, pengkuran daya tanhan ototo lengan push-up, daya tahan otot perut sit-up, dan kelincahan mengunkan ilionis aglity run tes, item itu smeua bagian dari parammeter tes pengkuran olahraga. Tes pengkuran olahraga merupakan instrumen tes yang berkaitan dengan aktivitas tubuh mansuia yang nantinya dikorelasian dalam angka sehingga dapat melihat kebugaran secara kuantitatif yang berisi data-data dan angka dalam setiap tes yang telah dilakukan (Gumantan and Mahfud, 2020)

SMK Kridawisata Bandar Lampung merupakan sekolah yang memiliki kegiatan aktivitas yang banyak. Kegiatan ektrakulikuler olahraga secara baik dilaksanakan dengan tersukur yang selalu keberlanjutan dalam setiap minggunya.Akan tetapi untuk melihat kebugaran jasmani dan melakukan aktivitas program latihan belum berjalan dengan baik. Sebelumnya aktivitas olahraga belum mengukur parameter tes kebugaran jasmani hanya melakukan proses pembelajaran olahraga yang belum berkolerasi dalam peningkatan kebugaran jasmani. Dengan melihat permsalahan itu tim pengabdian Univeristas Teknokrat Indonesia melakukan kegiatan pengabdian masyrakat yang membuat program latihan yang sistematis dan memberikan edukasi tentang parmater tes dalam tingkat kebugaran jamsani seseorang yang nantinya semoga dapat memfasilitasu dalam aplikasi pembuatan program latihan 


\section{METODE PELAKSANAAN \\ Tempat dan Waktu}

Kegiatan pengabdian ini dilaksanakan di SMK Kridawisata yang terletak di Sukarame Bandar Lampung . Kegiatan pengabdian ini dilakukan pada bulan April 2021-Juni 2021.

\section{Khalayak Sasaran}

Sasaran dalam kegiatan pengabdian ini yaitu siswa yang mengikuti ekstrakurikuler olahraga di SMK Kridawisata

\section{Teknik Pengumpulan Data}

Pengumpulan data dilakukan dengan mencari informasi terkait dengan permasalahan yang terjadi. Dalam hal ini penulis menggunakan beberapa cara dalam proses pengumpulan data, antara lain:

1. Wawancara dan Observasi

Wawancara dilakukan guna mengumpulkan data terkait dengan permasalahan langsung dari pembina, pelatih, dan peserta ekstrakurikuler olahraga. Observasi dilakukan langsung pada saat proses latihan dan tes kebugaran dilakukan.

2. Pelatihan

Pelatihan dilakukan dengan memberikan materi terkait dengan program latihan kebugaran jasmani

3. Tes Kebugaran

Tes kebugaran Jasmani untuk mengukur tingkat kebugaran jasmani setiap siswa

\section{Metode Pengabdian}

Kegiatan pengabdian ini dilakukan berupa pelatihan pembuatan program latihan kebugaran jasmani. Hal ini dilakukan guna membantu dalam meningkatakan kondisi fisk siswa dalam melakukan aktivitas belajar. Kegiatan ini dimulai dengan melakukan dengan observasi masalah terkait dengan permasalahan yang terjadi. Selanjutnya dilakukan pelatihan pembuatan program latihan. Setelah itu dilakukan tes pengukuran olahraga yang mengukur kebugaran jasmani. Sebelum dan sesudah dilakukan. Berikut ini

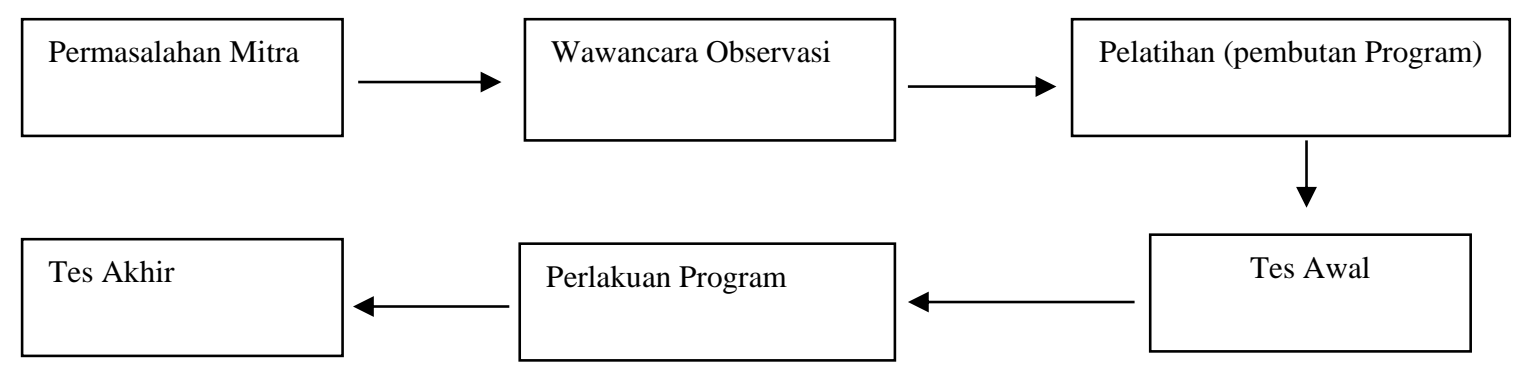

Gambar 1. Tahapan Kegiatan Pengabdian

\section{HASIL DAN PEMBAHASAN}

Hasil kegiatan pengabdian ini berupa kegiatan pelatihan dan pendampingan pembuatan program latihan kebugaran jasmani pada ekstrakurikuler olahraga. Kegiatan ini memiliki peranan untuk membantu siswa mengetahui aspek kebugaran, pola latihan olahraga dan instrume tes kebugaran jasmani dan kesehatan. 
Berikut ini kegiatan yang dilakukan pada saat kegiatan dilaksanakan:

1. Perlatihan pembuatan program latihan

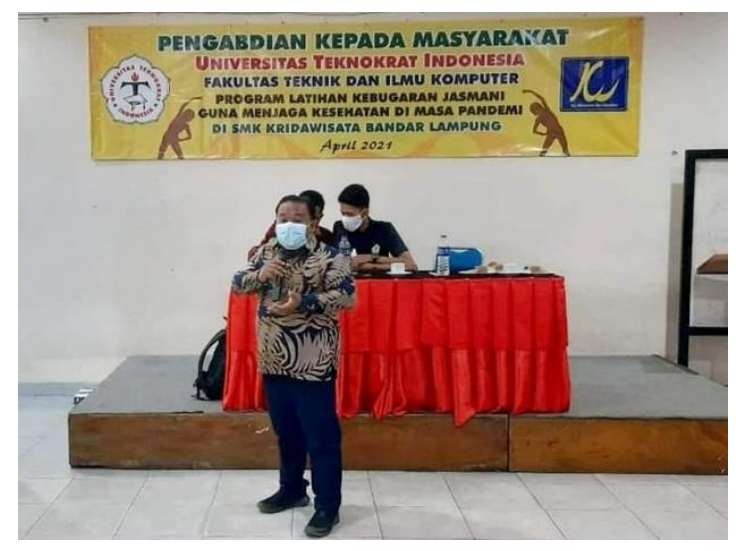

Gambar 2. Pelatihan Pembuatan Program

Pembuatan program melakukan analisis kebugaran jasmani permaismg-masing siswa yang nantinya akan dirumuskan dalam sebuah program latihan olahraga yang dilakukan selama tiga bula dengan aplikasi kebugaram yang terkontorl oleh tim pengabdian.

2. Pemaparan Kebutuhan Energi Tubuh

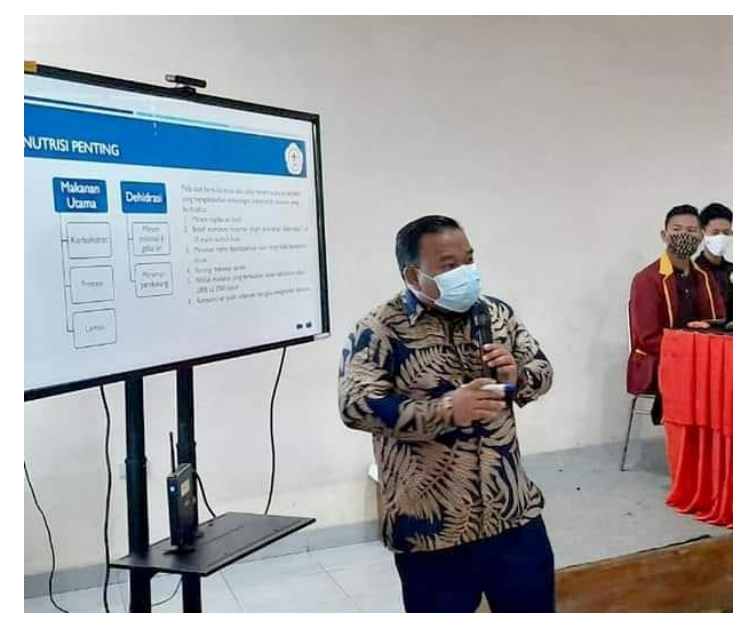

Gambar 3. Pemaparan nurtisi tubuh

Pemaparan nutrisi tubuh berfungsi ketika melakukan tretmen dan perlakuan program latihan siswa memahami asupan makan yang akan dimakan sehingga tidak terjadi overtraning dan kekuran asupan makanan dalam tubuh kita.

3. Tes Fisik Awal dan Akhir test 


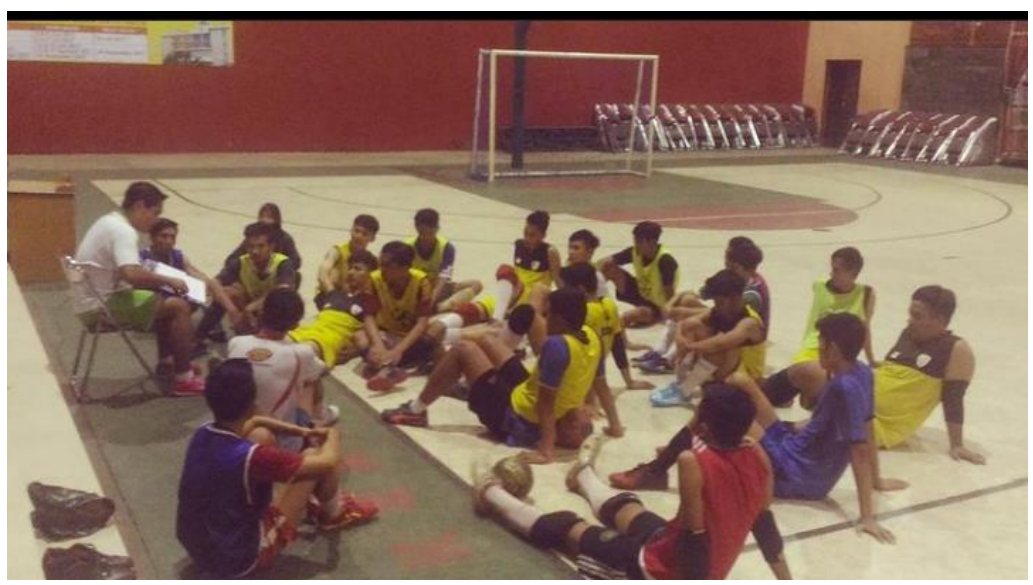

Gambar 4. Tes Fisik

Tes fisik berupa tes aal dan tes akhir dalam aktifitas pengukran olahraga melihat tingkat kebugaran siswa ketika melkaukan isntruen-intrumen tes kebugaran jasmani yang nantiknya terlihat sevara jelas dalam kebugaran siswa di SMK Kridasiwisata Bandar Lampung

Hasil dalam test ini dapat dilihat pada hasil tes awal dan tes akhir yang dilakukan. Tes ini digunakan dengan menggunakan angket. Hasil tes yang didapatkan dapat dilihat pada tabel berikut:

\begin{tabular}{lc}
\hline \multicolumn{1}{c}{ Hasil Tes } & Nilai Rata-Rata \\
\hline Tes Awal & $65 \%$ \\
\hline Tes Akhir & $85 \%$ \\
\hline
\end{tabular}

Tabel 1. Hasil Tes Awal dan Tes Akhir Kegiatan Pengabdian

Berdasarkan tabel diatas didapatkan bahwa rata-rata klasifikasi tingkat kebugaran jasmani sebesar $65 \%$. Setelah dilakukan program latihan selam atiga bulan dilakukan tertmen latihan yang disesuakan dengan program yang letah dibuat oleh permasing-masing siswa itu sendiri. Selanjutnya setelah dilaksanakan tes akhir pengkuran olharaga kebugaran jasmani sebesar $85 \%$. Rata-rata peserta telah mengetahui kegunaan tes kebugaran berdasarkan cabang olahraga dan telah mengetahui kebugaran jasmani permasing-masing siswa

\section{KESIMPULAN}

Berdasarkan dari kegiatan yang dilaksanakan. Pelatihan pembeuatan program latihan kebugaran jasmani di SMK Kridawisata Bandar Lampung berdampak positif dan meningkatkatkan kebugaran jasmani Peningkatan hasil tes dari tes awal 65\% dan tes akhir $85 \%$ menunjukkan keberhasilan kegiatan ini.

\section{UCAPAN TERIMA KASIH}

Ucapan terimakasih kami sampaikan pada Universitas Teknokrat Indonesia yang telah mendukung kegiatan ini melalui hibah pengabdian kepada masyarakat. Kami ucapkan juga terimakasih kepada pihak SMK Kridawisata Bandar Lampung yang bersedia dan berkenan menjadi mitra pada kegiatan pengabdian ini.

\section{REFERENSI/DAFTAR PUSTAKA}

Adhi, R. and Gumantan, N. A. (2020) 'Sport Science and Education Journal Indonesia Peningkatan Kemampuan Vertical Jump Peserta Ekstrakurikuler Bolabasket Sman 1 Pagelaran Sport Science and Education Journal', 
Sports Science And Education Journal, pp. 1-12.

Alamsyah, D. A. N., Hestiningsih, R. and Saraswati, L. D. (2017) 'Faktor-Faktor Yang Berhubungan Dengan Kebugaran Jasmani Pada Remaja Siswa Kelas Xi Smk Negeri 11 Semarang', Jurnal Kesehatan Masyarakat (eJournal), 5(3), pp. 77-86.

Annisa, D. F. and Ifdil, I. (2016) 'Konsep Kecemasan (Anxiety) pada Lanjut Usia (Lansia)', Konselor, 5(2), p. 93. doi: 10.24036/02016526480-0-00.

Gumantan, A. et al. (2020) 'Pemberlakuan New Normal Dan Pengetahuan', Sport Scienc and Education Journal, 1(2), pp. 18-27.

Gumantan, A. and Mahfud, I. (2020) 'Pengembangan Alat Tes Pengukuran Kelincahan Mengunakan Sensor Infrared', 05(02), pp. 52-61.

Mahfud, I. and Gumantan, A. (2020) 'Analisis imt (indeks massa tubuh) atlet ukm sepakbola universitas teknokrat indonesia', 3(May), pp. 9-13.

Mahfud, I., Gumantan, A. and Nugroho, R. A. (2020) 'Pelatihan Pembinaan Kebugaran Jasmani Peserta Ekstrakurikuler Olahraga’, Wahana Dedikasi : Jurnal PkM Ilmu Kependidikan, 3(1), pp. 56-61. doi: 10.31851/dedikasi.v3i1.5374.

Prasetio, E. et al. (2018) 'Tingkat Kebugaran Jasmani Berdasarkan Indeks Massa Tubuh Pada Siswa Smp Negeri 29 Bengkulu Utara', Kinestetik, 2(2), pp. 166-172. doi: 10.33369/jk.v2i2.8738.

Setiyani, R. Y. (2018) 'Perbedaan Tingkat Kecemasan Pada Mahasiswa Baru Di Fakultas Ilmu Kesehatan Dan Non Fakultas Ilmu Kesehatan, Universitas 'Aisyiyah Yogyakarta', Jurnal Psikologi Integratif, 6(1), p. 16. doi: 10.14421/jpsi.v6i1.1469. 